Проф. др Саша Кнежевић Филозофски факултет Пале Универзитет у Источном Сарајеву knezsa@yahoo.com

\title{
ФЛОРАЛНО ФАУНАЛНА СИМБОЛИКА КОЧИЋЕВЕ ПРОЗЕ
}

У прози Петра Кочића флорално-фаунална симболика присутна је у већем броју приповиједака. Како је и сам писац свој књижевни опус у великој мјери ослањао на српску народну традицију и биљни и животињски свијет његових приповиједака у великој мјери се да самјерити усменом баштином. Отуда је симболика биљног и животињског свијета Кочићевих приповиједака у највећој мјери сагласна са оном коју оне имају у српској митологији и народном вјеровању, чиме прије свега доприносе колоризацији слике стварности Кочићевог дјела.

Кључне ријечи: Петар Кочић, приповијетке, флора, фауна, симболика, усмена традиција.

Већ на основу самих наслова Кочићевих приповиједака да се наслутити у коликој је мјери флорално-фаунална симболика заступљена у његовом опусу: Јаблан при чему је по биљци именован бак, Јелике и оморике, Змијағе, Вуков іај. За овај рад је остављена по страни, али се никако не смије заборавити ни наслов његове једночинке Јазаваи, üpeg суgом, тим прије јер је Давид пред судију довео злотвора који му је „појео читаву њиву кукуруза!“1 (192). У начелу

1 Сви цитати из дјела Петра Кочића наведени су према: Петар Кочић, Јауци са Змијаға, Нови Сад: Матица српска; Београд: СКЗ, 1972. 
се биљке које се појављују код Кочића могу подијелити у три групе: дрвеће, траве и житарице и друге ратарске културе, које ћемо именовати знатно поетичнијим називом - биљке хранитељке.

Кочићеви описи природе су у функцији цјелокупне атмосфере у којој се одвија радња његових приповијетки. Они су незаобилазни дио специфичног хронотопа Крајине йog укойаиијом. С обзиром на то да се описи природе, односно мјеста догађаја по правилу дају на почетку приповијетке, они упућују на централно осјећање стварности које нуди приповијетка. У приповијеци Гроб слайке gуше чија нам уводна реченица „Упекло сунце - сажеже све!“ (77), наговјештава апокалиптичност потоње приповијести, писац уводним пасусом нуди сликовит опис цјелокупне атмосфере у којој се она одвија: „Пријатан мирис скорушеног планинског сијена, с тешким смоластим задахом мртвих, спарених јела и оморика, некако тешко пада човјеку на душу у овој загушљивој планинској жези“ (77). За Јована Дучића (1989: 45) један од Кочићевих најзначајнијих доприноса српској литератури јесте у вјештини колоризације слике српског села и сељака апострофирајући: „да би један писац био у књижевности сликар, треба да има нарочито моћан сенсибилитет, и једно скоро сполно и варварско осећање за ствари у природи“.

У складу са тематиком његових приповијетки уз биље неријетко стоје атрибути опаљени, спарушени, поцрњели, сасушени, увели, суви и сл. У овом случају дрвеће није тек спарено, него мртво, чак испушта и мртвачки задах. Како по истраживачу босанских старина и вјеровања народних Емилијану Лилеку (1894: 368) „Билина може по вјеровању овдашњег народа такођер бити стан какву душевну бићу“ проналазимо да је то случај и са два дрвета из текста. Јела је, што је опште познато, станиште виле, а оморика демона, за шта Чајка- 
новић (1994: 199), позивајући се на Лилека, нуди примјер из пјесме 3иgaюе ћуйрuје у Вишеіраgy: „Дође Дрина мутна и помамна, / Помоли се витка оморика, / Те удари у ћуприју кулу“, на основу чега се нуди закључак како са смрћу дрвета не умире само стабло, него и његов становник у којем се налази његов дух.

Фаунална симболика дрвета у овој приповијеци кулминацију достиже реченицом у којој Дуле показује на кућерак Слатке Душе: „Ено, ено тамо на крај села, у ној долини, више које коิ у сумаглици трепере двије јасике...“ (78). Објашњење симболичне детерминације јасике као сјеновитог дрвета Чајкановић проналази у тексту Хајдара Фазлагића (1895: 467-468) Шӣоваюе йрешне који се позива на причање неког старог муслимана којег је срео док је овај іонио йовар gрва кући: „кад су немруд (Нимрод) и његови људи Ибрахим-пејгамбера (Алахом) бацали у ватру, мазга је доносила дрва, а зелембач је ватру потпухивао. Но пошто не хтједе трешња да гори, то је мазга донијела јасику, која је радо горјела. На то се Бог ражљутио, те је мазгу, јасику и зелембача газаб учинио (проклео), а трешњу је благословио и посветио. То се божије проклетство и данас познаје на мазги и јасики; јер мазга од онда не може свога евлада (подмлатка) имати, а јасикин лист увијек трепери“.

Фазлагићев текст је временски, па и просторно, веома близак Кочићу и потврђује нам оновремено постојање веома животворног вјеровања о магијској природи биља које је постојало у народу и које је несумњиво познавао и Петар Кочић, а што на веома интересантан и сликовит начин описује њихов, раније споменути, савременик Емилијан Лилек (1894: 368): „Како други народ, овако држи и овдашњи народ до тога, да билина мисли и ћувствује, да има глас, крв и тјелесне потребе, по томе душу и тијело - све као човјек“. Назив Лилековог текста из Гласника земалької музеја, на који се Веселин Чајкано- 
вић иначе радо позивао, Вјерске стиарине у Босни и Херцеїовини, а који доноси мноштво веома занимљивих, у то вријеме живих фолклорних образаца, потврђује да су сви ти несумњиво претхришћански култови итекако имали снажну ритуалну, па и својеврсну религијску функцију у вријеме када их је Лилек сакупљао, дакле, у вријеме у коме је и Кочић писао своје приповијетке.

Поред јеле и оморике ${ }^{2}$ у Кочићевим приповијеткама се од шумског дрвећа јављају и смрека или смрчика, букве и јаворови. Приповијетка Вуков і $а j$, при чему је назив шуме антропонимског постања, типичан је примјер коришћења вишезначне симболичности која је неријетка код Кочића. „О рођењу његовом испредале су се дуге и различите бајке“ (245), међу којима је и она да га је мајка изгубила у некој буни, а да су њену узалудну потрагу прекунули гладни вуци, „кад су га нашли чобани и надјенули му име Вук“, с временом се припитомљавао међу Босанчиће, да би на крају постао „тих и смирен као овца“. Његов magma opus коме је посветио цио свој живот било је стварање чудесног гаја од закржљале шикаре повише босанчића кућа. Вук се никада није у цјелости припитомио, али је он припитомио своју око-

2 У Кочићевим приповијеткама јеле и оморике својом висином којом стрше изнад крајолика јасно симболизују друкчијег човјека којег његова издвојеност чини усамљеним. С обзиром на то и њихова је функција повезана са атмосфером општег безнађа, те не чуди што наилазимо на овакве описе: „Све стоји усправ, тихо, побожно; и црне, жалосне јеле“ (90), „измеђ неколико јела и оморика“ (103), „Високе оморике под тешким ињем стадоше се лагано њихати и повијати, шкрипећи језиво и збацујући са себе пуне прегршти снијега" (262). Само на једном мјесту ово дрвеће се помиње као дио шуме и опет у злослутној функцији када Мика оптужују Мргуду: „А кад те Лујо Крстанов пресреће у јелику, ти шутиш“(86). Осим што „Четинарске шуме високих гора представљају у усменој поезији дивљину и опасне пределе“ (Самарџија 2014: 5), јасна је и асоцијација да је јелик заправо вилинска настамба, чиме се еротски контекст Микине опаске пребацује у митски код. 
лину и то дрвећем којем народно вјеровање приписује опречне особине. Буква има функцију животворног дрвета, то се у самој причи потврђује чињеницом да је кора младих буквића спасила сеоску сиротињу за гладних година за разлику од јавора који је типично сјеновито дрво повезано са култом мртвих, али и са пјесмом јер се од њега израђују најбоље гусле. Тај гај необичног имена и поријекла био је за Змијањце „коิ наша светиња једна“ (248) и отуда не изненађује што је постао симбол пркоса и отпора окупатору. То је онај јединствени однос сељака према земљи који, као и Андрић (1976: 176) проналазимо у сваком Кочићевом слову „Та земља је постала светињом због које је он у току столећа и мољакао и ласкао, и лагао и варао, и обијао прагове власти и судова, и најпосле и у крв газио понекад“. Народни је бунт угушен у крви између осталог и Вуковој, „немилосрдна туђинска рука исијече и сасијече све“, а „ојађено Змијање обави се у тугу и жалост голему“ (251), јер људи који живе у потпуном садејству са природом са њом заједно и расту и умиру.

Отуда никако није случајно да код Кочића наилазимо на једну алегоричну причу, заправо поетиду, каква је Јелике и оморике. Њена поента исказана је реченицом: „Јелике моје и оморике, и ја се више ничему не надам; и мој је живот као и ваш пун њежне, дубоке чежње; али - срце пишти, нико га не чује, сузе теку, нико их не види“ (95). У крајње лирски интонираној интимној исповијести у јеликама и оморикама препознајемо разочараног човјека уко-

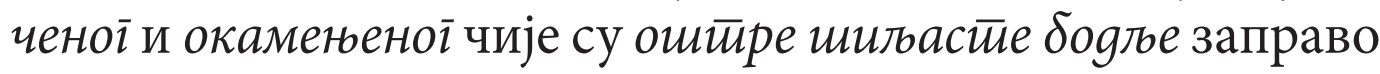
тек скаменене сузе „а њихова зелена боја, то је чежња за вјечито зеленим прољећем, које нам неће никада доћи!“ (96). Овај крајње дефетистички став са краја приповијетке добија додатно на јачини у компарацији са опозитним уводом „Са чистог, блиставог неба просипа се жива, треперава, весела свјетлост“ (95). За пораженог горостаса радост буђења живота и природе само је додатни разлог за несрећу, јер је њему све једнако „и прољеће и љето и јесен 
и зима. Оне су увијек хладне, суморне, тужне, јер, - срце пишти, нико га не чује; сузе теку, нико их не види“ (95).

Та грудобоља, којој нема ни мјере ни самјерења, у опозицији је са уводним описом мирисних пропланака у рано прољеће, на којима „мирише дријемовац“ (95), заправо каћун цвијет познат по својој гиздавости. Вук (1972: 266) у свом Рјечнику ову одредницу појашњава пословицом „Ођео се као каћун“, додајући да је то и име волу „који је врло лијеп“. Дријемовцу се у тој пасторалној сцени на влажним пропланцима прикључују „задовољни, кочоперасти кукуријек“ (95) и „са сувих присојних камењара [...] миришљаве љубичице“. Нису случајно баш ова два цвијета дата у истој слици, јер у љубавној народној пјесми, једнако просторно позиционирани они представљају мушки и женски принцип „Кукуријек с брда виче ожените ме / Љубичица из долине: поведите ме“. Даје Кочић поред краћих пасажа у приповијеци „Пјесма младости“ и једну цијелу народну лирску пјесму од које је за нас интересантан уводни дистих: „Расцвјето се ђул у башти / Милодув ${ }^{3}$ се размирисо“ (125), али и она је пјевана болно и однекуд из даљине.

Милодух, милодув, милоду је због свог паронимијског значења веома чест и рад гост у лирским народним пјесмама са тематиком љубавне магије:

„Милодуа, да се милујемо;

Калопера, да ме не отера;

Љубичице, да ме свагда љуби;

Каранфила, да се не карамо;

Чубрацвећа, да ме добро чува;

Босиока, да м' несмеће с ока;

А невена, да му срце вене

Самдокаса и околочепа.“

(Караџић 1841: 468)

На примјеру пјесме Деветиоро биље можемо најбоље потврдити како се афирмише магијско-етимолошки код „милоgува gа се милујемо, који лежи у асоцијативној структури ове биљке“ (Карановић 2012: 1111). 
И овдје је то живо процвјетало цвијеће тек у функцији антипода суморном осјећању пишчевом. По правилу цвијеће је код Кочића мртво и такво наговјештава судбину јунакиње приповијетке. У Кроз свјеитлосии то је „увела кита милодува“ (109), Мріууди: „Испод тврдог, сламног поглавача мирише суво босиље, девесмиље и црвени, увели ђулићи“ (88), у Кроз маїлу из планинске брвнаре „се шири јак мирис сува цвијећа“ (102). Марушка у часу кад су је жене „почеле за вјенчање пресвлачити и китити босиљем [...] суну ко̂ луда у маглу“ (105). Босиљак је омиљен и сигуран апотропајон у народном вјеровању код Срба и није ни чудо да их је пратио „кроз све озбиљније прилике у животу“ (Панчић 1868: 251), па наравно и у свадбеном ритуалу. Отуда је и за Марушку кићење босиљком представљало тај пресудни чин којим се потврђује њена несрећна судбина на коју не пристаје и од које бјежи у маглу, јер „жива нећу за њег'! [...] Волим да ме вуци истргају, него да ме се његова рука дотакне!“ (107), како „врисну и помамно шкрипну зуб'ма“, сакривена иза „једног крошњастог огољеног трна“ (104).

Међу биљем треће групе коју смо назвали биљке хранитељке код Кочића срећемо жито, а издвајају се зоб коју Лујо даје Јаблану да се заслади, десетар сељаке вија у 3лорекову зоб, па чак се њоме мјери и количина ракије коју је Симеун попио „ако Симеун није досада попио толико ракије да би се на њој, кад би се пуштила кроз бадањ, могло самљети двадесет улчека сирове зоби!“ (142), и на првом мјесту брадали кукуруз, што потврђује Чајкановићев став: „У култу има кукуруз велики значај, нарочито у оним крајевима где је он главна људска храна“ (Чајкановић 1989: 128). На Змијању „брадали кукурузи сморено шуште, жудни. Прежудни кише“ (217), а шум Врбаса из даљине као да им се руга, док посљедњу наду за спас сјетве и народа стари Милић Вујиновић види на небу: „Вијају се орлови, могло би и кише бити“. Ничега 
код Кочића нема оптимистичног па не чуди да и на „кукурузе, који су се истом почели зрнати“ (74) падају вране из околних шумарака не осврћући се на чуваре који хајкају и страшила која лепршају на оградама.

Помиње Кочић и воћке, у причи Коg Марканова йочка стабла трешње, ${ }^{4}$ „осамљени редак трешања изнад Чергића наслона“ (90), крушке „крошњаста крушка дивљака код Марканова точка“ (90), или плодове, опет увеле, миришљаве јабуке и крушке, али и специфично „Позно, планинско воће“ (103), „дугуљасте бобице бијелог трна“б и „набубриле трњине“ (102-103). И њихов помен је у функцији свеопште чежње и туге исказане на крају приповијетке „Е, мој брате, тешко нами! Ми смо ти једни, што се каже, незаробљени робови: код куће, а брез куће; код земље, а брез земље; код постојбине, а брез постојбине“ (94).

Ипак, централно мјесто међу воћкама, првенствено захваљујући приповијеткама из циклуса о Симеуну ђаку, заузима шљива. Шљива је света воћка у староставној филозофији Симеуна Пејића Рудара, ђака од манастира Гомионице. Он спремно и аргументовано стаје у њену заштиту када Мићан почне да је куне и назива „кугом људском“ (157). Њену сакралну природу Симеун аргу-

4 По Чајкановићу (1994:199) трешњин религијски значај може бити двојак, али смо из наведеног етиолошког предања видјели да је муслимани поштују као свето дрво.

5 „Грађа српске усмене прозе и етнографске чињенице углавном су усклађене када су у питању појава и значење које у њима има крушка. Она се у њима креће од светог дрвета, станишта добрих богова, дрвета које доноси добро и штитит човека, до дрвета које је демонско, зло, на коме живе разна демонска бића која прете и повређују човека“. (Поповић 2013: 37)

6 Мада би наша првобитна асоцијација на трн била негативна, он је у српским народним вјеровањима „врло моћан утук против свих злих демона. Као такав, има он надомак gевесиљ [...], то јест, он сам садржи толику моћ колику gевей других магичних биљака заједно“. (Чајкановић 1994: 200) 
ментује необоривим доказом „да ракија није добра и да ракија није од бога, не би се она тако зорли штимала у нашој светој и православној Русији“ (157). Врхунац игре Кочић даје у истинској здравици коју Симеун чата шљиви „не ударај ни на шљивин род ни пород, родио он нама и по дрвету и по камену на страх врагом, већ ми наточи једну чашу, па ћу вам сад приповиђети шта све ракија учинити море на ползу светом православију“ (158). Ракија и(ли) шљива, а код Кочића су оне у синонимној међузависности, иницирала је Исиичнитии зулум Симеуна ђака. У ироничном кључу Кочић Симеунов зулум повезује са лейешинама које су у глуво доба тог прољећа покојном Партемију стизале „из Црне Горе и од српског књаза из Београда“ (136), које подстичу Симеунов одлазак у ешкију праћен стиховима из Вишњићевог Почейка буне ӣройив gахија, да би на крају суштину њиховог незадовољства поентирао сликом: „Шједе они мамурни. Шљива премакла, па се забринули. Кажем вам, ниђе ни капи ракије“ (137). Како Кочић сам себе најбоље тумачи тако по принципу „кад Вла', што 'но веле Турци, у'вати вурсат - мјере му нема!“ (137). Симеун и Партенија полазе да казне Гавру Брадару испред чије се куће јединог те јесени пуши ракијски казан, јер они сматрају како је он помислио „шљива је премакла, сад ћу шићарити“ (137). Дакле, у мамурлуку и страху да не остану без свете амброзије Партемија и Симеун започињу представу која се умало не завршава трагично, а у општој завршној катарзи они на крају „отраше сузе и шједоше пити“ (140).

И фаунална симболика у Кочићевом дјелу се исказује као интегрални дио генеолошког јединства који је Андрић зналачки објединио триптихоном земља, тууди u језик. Отуда скоро да и није могуће симболику животињског свијета Кочићевих приповиједака самјеритити значењима која су им приписивана у народним вјеровањима кад је ријеч о домаћим животињама. Во, сим- 
бол снаге и мушког принципа, којег су понегдје Срби као полажајника у кућу уводили (Кулишић и др. 1970: 72), код Кочића је и више од пријатеља човјековог. Лујо Јаблана мази, милује и тепа му „Де, де, да се појубимо! Пољубише се“ (73). Јаблан је много више од бака, много више од животиње, много више од Лујиног најбољег друга. Он је симбол пркоса и снаге свога краја. Он ће као „лукави мегданџија“ (76) преварити царског бака и донијети немјерљиву радост цијелом Змијању. Велики млаз крви који је шикнуо испод Рудоњиног врата крвна је освета за све муке које од његовог господара трпе и трпили су Змијањци. Он је испунио Лујин сан и њему у част Лујо задолига, прослављајући једну велику побједу у мору малих континуираних пораза народних. Јабланова је побједа побједа Змијањаца и Змијања, па отуда, крајње необично за Кочића и цијела приповијетка има оптимистичан завршетак „Јаблан стоји поносито на мејдану, а планински врхунци силно - силно одјекују“ (76).

У Кочићевим се приповијеткама најчешће спомиње коњ, алабаш, брњаш, зекан или ат, онај који „језди и стриже кроз маглу“ (102), онај којег помамни јахач „све јаче, оштрије боде мамузама“ (110), или ат Симеуна ђака који је саставни дио његове мејданџијске опреме. Посебно мјесто припада ономе Мрачајског проте за кога веле да је „као ала!“ (115), с којим газда разговара, тепа му „Магајце један! Како си ми, како си ми, магајце један?“ (118). Само коњ очовјечује ту никад неразјашњену мрачну личност „Воли тебе твој прото, магајцино једна стара!“ (118), мизантропа који своју мржњу не ограничава на давно престављеном Џибукарди и његовим Џибићима, онога који сурово кажњава пса Зељова и по њему шаље „поздраве у пако̂ старом Џибукарди“ (117), само зато што није објавио долазак непозваних гостију.

Да су животиње интегрални дио стварности књижевног дјела и првенствено у функцији сликања књи- 
жевних јунака показују нам и два опречна примјера помена кобиле у двије Кочићеве приповијетке. У Буриним зайисима несрећни Ђуро ждребну је Максимову кобилицу више „водио нег’ ја̂’’“ (61), чиме се показује самилост сељака према тим племенитим животињама и њихово поштовање плодности и рађања, али код Кочића ће у сасвим друкчијим околностима и стању мамурног растројства Партенија у „Истинитом зулуму Симеуна ђака“ наредити Мићану „Симеуну опреми мог 'ата, мени зекана, а ти себи осамари ону ћораву кобилетину“ (137). Кочићеви јунаци су неријетко добро психолошки испрофилисани чему често посебно доприноси опис њиховог односа према животињама.

Код Кочића је чак и животињски свијет више условљен политиком, него митологијом, као у „Ракијо мајко!“ гдје голему несрећу која је била узрок њиховог пијанства Симеун објашњава: „На недељу дана иза укопације [...], пометиљише нам се овце. ${ }^{7}$ Од тог времена пође сваком нагоре у овој земљи, а и овој светој обитељи. Почеше нам овце полијегати и умирати“ (158). С обзиром на природу и узрок катастрофе, сви покушаји да се народном магијом спасу није могла ни дати адекватног резултата. „Чатали смо масла, светили со, писали записе, бацали водицу по тору; све, све смо радили и чинили, али ништа не помаже“ (158).

То је она несхватљива и неухватљива несрећа која само дође и однесе све пред собом. Дође кобни дан кад се gиїну врући йланински вјеитрови кад човјеку преостане једино да немоћно гледа како „завитлаше млаку прашину

Овце и јагњад помињу се неријетко као симбол плодности и просперитета и то као дио ма̂ла, у паралелизму „жене се близниле, овце се близниле, козе се близниле“ (254), или дио пасторалне слике „По округлој долини расуле се овце с јањцима“ (110), али и као недужна жртва Ђурине глупости „Оборио сам најбоље јање“ (67). 
у ковитлац, расипљући је по торовима, стајама и њивама његовим. Тих дана је обноћ је у торовима блечала марва, торске су љесе болно, као да цвиле, шкрипјеле, чобани су снивали немиле и чудесне снове, а пси су некако тужно, претужно урликали и завијали као гладни курјаци усред зиме на планини“ (256). Овом сликом започиње пад Реље Масларића оног што у пословицу народну бјеше ушао, „Што си се толико диго̂, нијесу на теби токе и илике Реље Масларића!“ (254), оног којем је до тог судњег дана све „напредовало, расло, бујало, множило се и ширило у недоглед“ (254). Засигурно је трагичног јунака приповијетке Кроз мећаву имао на уму Иво Андрић (1976: 183) исказујући занимљив, али тачан суд о Кочићевој слици Босне: „По том њеном моралу појам имања и благостања, а поготово раскоши и сјаја, постао је, под таквим условима, готово неспојив са појмом независности, поноса, па и самог основног појма части“. Морао се и Реља Масларић свести на мјеру својих планинаца, морале су се на небу и над његовим газдинством појавити злослутне вране и орлушине. „Орлови ${ }^{8}$ мрлинаши, они грдни планински орлови огуљених, голих вратова и дугих, заоштрених кљунова почеше се вијати небом изнад стаја Рељиних и падати крај торова. Црне вране ${ }^{9}$ и гаврани у дугим широким јатима, кобно су и злобно грактали поврх мала његова, падајући са немилим крештањем на товне мрлине“ (256). Од те се пошасти није могао спа-

8 Када узмемо у обзир тумачење Александра Гуре (2005: 456) „Код Јужних Словена орлу се приписују посредничке функције: он остварује везу између горњег и доњег света, слободно узлеће на небеса и силази у пакао“, схаватамо како се у овој птици заправо огледа Рељина судбина.

9 „Све птице из ове групе сматрају се нечистим (ђаволске, проклете) и злослутним [...] Грабљивост и крвожедност који одликују пре свега гаврана, зближавају га у народним представама и обредима с грабљивцима као што је вук“. (Гура 2005: 397) 
сити ни Јаблан и њега „међу синим мрлинама нађоше мртва у тору“ (256).

Змијање, како му и само име каже, змијска је земља, змијски дом. Змија тај „најистакнутији вишезначни полифункционални животињски лик“ (Гура 2005: 208) најбоље симболише овај крај, ђавољи и врлетан, свијет живих који завиде мртвима, поднебље змајевитих јунака. Змија је у словенској митологији често представљена као чувар дома „Срби је зову змија чуваркућа“ (Гура 2005: 230), па би се отуда она могла схватити као симболична заштитница Кочићевог завичаја од свакојаких зулума и зулумћара.

Друга често помињана звијер у Кочићевим приповијеткама је вук или курјак чија се хтонична природа јасно потцртава и код Кочића. У чувеној суморној слици у приповијеци У маіли кулминацију представља њихово завијање „кад испод планине гладни и бијесни вуци урличу, па кад се човјеку, од страха и студени, у жилама крв леди, а у костима срж смрзава“ (102). Занимљива паралела се може повући и са атипичном брачном симболиком (в. Гура 2005: 92-93) која се код Словена везује уз вука и Марушкиним вриском „Волим да ме вуци истргају, него да ме се његова рука дотакне!“ (107), гдје се она између двојице нежељених младожења опредјељује за оног који ће је претворити у вампира (в. Гура 2005: 95).

За крај просто не смијемо пропустити чињеницу да се биљке и животиње у овим приповијеткама појављују и у пренесеном значењу, као што смо показали у насловима, па је тако Јаблан име вола, Вук име човјека, Змијање назив краја; Ђурђија у Мрачајском йройи пишти „ко змија у процјепу“, фантагонична Вида „наједном диже главу увис као змија“ (113), путић који води ка Мрачајском проти „као испребијана змијурина вијуга испод нас кроз завијене њиве“ (115). Кочић нас учи да постоји и мјера за дужину „пружај волова“ (91). У, по Исидори Секулић (1971: 71), најйесимистиччнијој Кочићевој приповијеци Кроз мећаву у уводној 
слици „Снијежне лепирице укрштају се у лету, ломе се једна о другу и шуште у тананом и меком шуму поврх њихових глава, а њих троје, старац напријед, крава за њим, за кравом Вујо, промичу чаршијом лагано и уједначено, стопу за стопом“ (253). Пахуље се именују сњежним лептирицама, а у општесловенској митологији „Са лептиром се пре свега повезују представе о души“ (Гура 2005: 365). На самом почетку приповијетке је, дакле, симболично наслућен и њен трагични крај.

Има наравно код Кочића и друкчијих примјера. Мргудину иреслайку крв Кочић описује „Лице смеђе, окошто, а остала снага саливена, једра, пуна као у надојена јањета“ (85). Још прпошнији опис дјевојачке љепоте проналазимо у приповијести Кроз свјеитлосй: „Кошуља јој се размакла на заобљеним прсима, а врело, животворно сунце пробило кроз прозор, па се распрштило по глаткој, влажној, бјеличасто мраморастој удољици између оне двије округласте месасте јабуке“ (112).

Богати флорално-фаунални свијет Кочићевих приповиједака првенствено се исказује кроз описе природе који су у потпуности у функцији тематике приповијетке и њене, најчешће мрачне, атмосфере. „Особеност је у Кочићевој дескрипцији да он зна да богату позицију приче не само обједини стилом и оквиром него и озари изврсним пјесничким потезима свјетлости преко цјелине слике и њене садржине, стварајући визуелно јединство између човјекова свијета и природе“ (Бегић 2016: 92). То јединство човјека, јунака приче и природе као позорнице приче, чине уникатну сцену на којој свијет биљака и животиња постаје садејствени чинилац радње и веома битна стилска маркација приповиједног поступка. Њихова симболика, проистекла из народних вјеровања, дјелотворна је копча којим се Кочићев наративни поступак везује са српском усменом књижевношћу. На тај начин Петар Кочић се повезује са традицијом из које је проистекао, уједно на маестралан начин постајући њен интегрални дио. 


\section{Литература}

Андрић, Иво. „Земља, људи и језик код Петра Кочића“. Есеји и критичке, Сарајево: Свјетлост, 1976. 172-192.

Бегић, Мидхат. „Књижевно дјело Петра Кочића“. О срйским йисиима XX века, Андрићград: Андрићев институт, 2016. 87-132.

Гура, Александар. Симболика животиньа у словенској народној йраguиији. Београд: Бримо - Логос - Глобисино, 2005

Дучић, Јован. „Петар Кочић“. Моји сайуйници. Сарајево - Београд: Свјетлост - Бигз - Просвета, 1989. 41-68.

Карановић, Зоја. „Узори, Маро, равнине - поезија, магија, обред“.

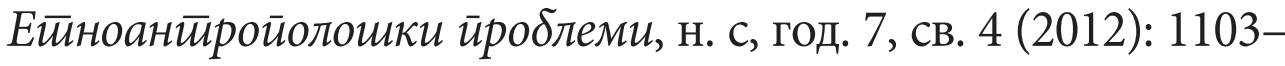
1116.

Караџић, Вук Стефановић. Срйске нароgне ӥјесме - књиїа ӣрва. Беч: Штампарија јерменскога манастира, 1841.

Караџић, Вук Стефановић. Срӣски рјечник, Београд: Нолит, 1972.

Кочић, Петар. Јауци са Змијаға, Нови Сад - Београд: Матица српска - СКЗ, 1972.

Кулишић, Шпиро и др. Срйски мит̄олошки речник. Београд: Нолит, 1970.

Лилек, Емилијан. „Вјерске старине из Босне и херцеговине“. Гласник Зематьскоі музеја, VI, април-јуни (1894): 368-388.

Поповић, Данијела. „Крушка у традиционалној српској култури у усменој прози“. Биле у йраgищионалној кулйури Срба, Нови Сад: Филозофски факултет, 2013, 31-40.

Самарџија, Снежана. „Танковрха јела и зимзелен бор“. Биље у

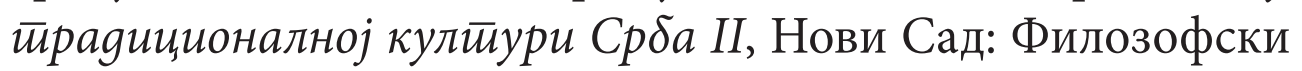
факултет, 2014, 5-18.

Секулић, Исидора. „Петар Кочић“. Оілееgи и зайиси, Нови Сад - Београд: Матица српска - СКЗ, 1971, 67-90.

Фазлагић, Хајдар. „Штовање трешње“. Гласник Земаљскоі музеја, VII, јули-септембар (1895): 467-478.

Чајкановић, Веселин. Речник срйских народних вероваға о биљкама. Београд: СКЗ - БИГЗ - Просвета - Партенон, 1994. 
Saša Knežević

\section{FLORAL-FAUNAL SYMBOLISM OF KOČIĆ PROSE}

\section{Summary}

In Petar Kočić 's prose floral-faunal symbolism is present in a number of short stories. As a writer his literary work is based to a large extent on the Serbian national tradition, and the wildlife of his short stories largely is based on the oral heritage.

Key words: Petar Kočić, novels, flora, fauna, symbolism, oral tradition. 